\title{
PHYSIOCHEMICAL ANALYSIS OF PRETREATED BIOMEDICAL WASTES
}

\author{
SREEREMYA S, RAJIV P* \\ Department of Biotechnology, Karpagam University, Karpagam Academy of Higher Education, Coimbatore, Tamil Nadu, India. \\ Email: rajivsmart15@gmail.com
}

Received: 30 June 2017, Revised and Accepted: 19 August 2017

\section{ABSTRACT}

Objectives: The main objective of the research is to pretreat the Category III biomedical waste using Bacillus flexus and to assess the physiochemical properties of pretreated biomedical waste.

Methods: Major pretreatment methods such as physical (P), chemical (C), biological (using B. flexus) (B), physical and chemical, and physical, chemical, and biological method (PCB) were adopted for this investigation. The nutritional status was analyzed before and after the pretreatment. The physiochemical parameters such as $\mathrm{pH}$, electrical conductivity, moisture content, bulk density, cellulose content, and carbohydrate content were assessed.

Results: There was a significant difference between before and after the pretreatments of physiochemical properties. By treating, the biomedical waste with B. flexus has produced a drastic change in the cellulose level. By the assessment of each parameter before and after the pretreatment, the percentage of cellulose levels was found to be 35-40 in PCB method.

Conclusions: Hence, the study concludes that the pretreated biomedical waste contains suitable physiochemical properties, which may be used as a substrate for the production of vermicompost.

Keywords: Pretreatment, Biomedical waste, Biological treatment, Physiochemical.

(C) 2017 The Authors. Published by Innovare Academic Sciences Pvt Ltd. This is an open access article under the CC BY license (http://creativecommons. org/licenses/by/4. 0/) DOI: http://dx.doi.org/10.22159/ajpcr.2017.v10i12.21027

\section{INTRODUCTION}

The hospital waste generally termed as biomedical waste which includes human anatomical waste, needle and sharp waste, cellulosic waste, and discarded medicines [1]. As a result of global economic development, burgeoning population growth, and urbanization, solid waste generation is a growing social and environmental concern [2]. Among the solid waste generated globally, nearly $12 \%$ of the waste produced is from the hospitals and laboratories [3]. An increased percentage of biomedical waste is released every day without proper processing [4]. Improper disposal of biomedical waste causes serious health issues to human beings, and efforts were made to reduce a load of biomedical waste by major methods such as incineration, which has side effects [5]. Adoption of certain pretreatment strategies to degrade the Category III biomedical waste was implemented [6].

Among the biomedical wastes, the release and percentage of cellulosic waste discharged is more [7]. In the past years, efforts have been made to reduce the cellulosic waste by different pretreatment methods [8]. Pretreatment of Category III biomedical waste is to reduce the percentage of cellulosic waste [9]. Pretreatment can be implemented in three ways: Physical, chemical, and biological methods (PCBs) [10]. There were studies carried out in physical pretreatment, where it is found that approximately $4-5 \%$ of the cellulose content can be reduced by physical pretreatment.

Ohkuma has reported the efficiency of a chemical method for the treatment of waste by acid and alkaline chemicals [11]. Tahoun and Ibrahim have investigated the pretreatment of waste by physical method [12]. In the present study, biomedical waste was pretreated by physical, chemical, biological, and combination of each method, and to assess the physiochemical properties of before and after pretreated biomedical waste.

\section{METHODS}

Collection of biomedical wastes and chemicals

The biomedical wastes were collected aseptically from the hospitals and nearby laboratories of Palakkad $\left(10.7867^{\circ} \mathrm{N}, 76.6548^{\circ} \mathrm{E}\right)$, Kerala. The collected biomedical wastes were segregated (Category III biomedical wastes), placed in aseptic containers, and transported to the laboratory for further analysis. The chemicals for the analysis were majorly purchased from Sigma Aldrich.

\section{Treatment details}

Bacillus flexus was isolated aseptically from Gobar Gas Digester, Palakkad, Kerala. The morphological, microscopic, biochemical, and the degradation of cellulose were assessed by screening techniques. The pretreatment methods such as PCB methods were incorporated in the study. About $5 \mathrm{~kg}$ of biomedical waste (Category III) were treated by autoclaving the substrates at different temperatures $\left(121^{\circ} \mathrm{C}\right.$ for 15 minutes, 60 minutes, and 120 minutes labeled as P1, P2, and P3, respectively). About $5 \mathrm{~kg}$ of the biomedical waste (Category III) were treated with $0.25 \mathrm{M} \mathrm{HCl}$ and $0.25 \mathrm{M} \mathrm{NaOH}$ (labeled as $\mathrm{C} 1$ and $\mathrm{C} 2$, respectively). After the chemical pretreatment, the substrates were dried in hot air oven at $60^{\circ} \mathrm{C}$ [13]. Culture of B. flexus in basal media broth $(100 \mathrm{ml})$ was used for biological pretreatment. B. flexus was mixed with $5 \mathrm{~kg}$ of biomedical waste. The treatment details are B1: $5 \mathrm{~kg}$ of biomedical waste and $2 \times 10^{5}$ colony-forming unit (CFU), B2: $5 \mathrm{~kg}$ of biomedical waste and $4 \times 10^{5} \mathrm{CFU}$, B3: $5 \mathrm{~kg}$ of biomedical waste and $6 \times 10^{5} \mathrm{CFU}, \mathrm{B} 4: 5 \mathrm{~kg}$ of biomedical waste and $8 \times 10^{5} \mathrm{CFU}$, B5: $5 \mathrm{~kg}$ of biomedical waste and $10 \times 10^{5} \mathrm{CFU}$, and B6: $5 \mathrm{~kg}$ of biomedical waste and $12 \times 10^{5} \mathrm{CFU}$ and incubated for $12-24$ hrs aseptically [14].

\section{Analysis of physiochemical parameters}

Determination of $p H$, electrical conductivity (EC), bulk density, and moisture content

The $\mathrm{pH}$ of before and after pretreated biomedical waste was checked using digital $\mathrm{pH}$ meter [2]. The EC was estimated by digital EC 
meter [15]. The EC of before and after pretreated biomedical waste was assessed and expressed in $\mathrm{dSm}^{-1}$. The bulk density was analyzed as described by Sun et al. [16]. The sample (0.5 g) was weighed with the glass crucible and placed in the air drying oven for $18 \mathrm{hrs}$ at $105^{\circ} \mathrm{C}$ and cooled to room temperature in a desiccator and weighed [8]. The process was repeated until a constant weight was achieved, and thus making it free of moisture content [17].

\section{Estimation of cellulose}

The cellulose level of pretreated biomedical waste was evaluated [18]. A sample $(0.5 \mathrm{~g})$ was incubated to $100^{\circ} \mathrm{C}$ with nitric acid and acetic acid for 30 minutes. After centrifugation to $3000 \times g$ for 60 minutes at room temperature, a solution of $72 \%$ sulfuric acid was added. The spectrophotometric measuring was made against calibration curve of cellulose at $620 \mathrm{~nm}$.

\section{Estimation of hemicellulose}

The hemicellulose content of the pretreated biomedical waste was analyzed [19]. Nearly $0.5 \mathrm{~g}$ of the sample was taken and mixed with $0.3 \mathrm{M} \mathrm{NaOH}$ was added. The mixture was boiled for $2 \mathrm{hrs}$ in distilled water; then, it was filtered and washed until it becomes neutral $\mathrm{pH}$ and weighed initially. After weighing, the sample was dried at $105^{\circ} \mathrm{C}$. The difference between the sample weight before and after the treatment was the hemicellulose content.

\section{Estimation of carbohydrate}

The carbohydrate content in the pretreated biomedical waste was analyzed by dinitrosalicylic acid method [20]. Anthrone dissolved in sulfuric acid may be used for the quantitative determination of different carbohydrates. The mixture of samples was estimated at $620 \mathrm{~nm}$ using the spectrophotometer. The concentration of total sugar was calculated using a standard curve prepared from glucose. The amount of non-reducing sugar presented in the biomedical waste sample was determined by subtracting of reducing sugars from total sugars [21].

\section{RESULTS AND DISCUSSIONS}

The $\mathrm{pH}$ of the raw biomedical was found to be acidic $(6.9 \pm 0.087)$. The physically pretreated biomedical waste was moderately acidic $(5.3 \pm 0.035)$ (Table 1$)$. The chemically $(\mathrm{NaOH})$ pretreated biomedical waste was alkaline in nature $(8.0 \pm 0.09)$, and $\mathrm{HCl}$-treated biomedical waste was acidic $(5.1 \pm 0.95)$. The biologically pretreated samples were slightly alkaline $(7.1 \pm 0.226)$. The physically and chemically treated sample was slightly acidic $(6.9 \pm 0.15)$. The physically, chemically, and biologically pretreated biomedical waste was neutral $(7.0 \pm 0.296)$. The previous studies reported that the $\mathrm{pH}$ of physical pretreated cellulosic mass was found to be 5.0 [22].

The EC of the raw biomedical waste was $0.33 \pm 0.17 \mathrm{dSm}^{-1}$. The EC of physical, chemical, biological, physical and chemical, and PCB pretreatments were performed, and it was found to be range between $0.34 \pm 0.234$ and $0.59 \pm 0.23 \mathrm{dSm}^{-1}$ (Table 1 ). These results are in agreement with the previous study, the EC was low in physical pretreatment, and the EC was increased in the biological pretreatment [15].

The bulk density of raw biomedical waste was $0.59 \pm 0.22$ when physical, chemical, biological, and combination of pretreatment such as physical, chemical, and PCB pretreatment was performed, and there is an increase in the bulk density $0.82 \pm 0.077$ (Table 1 ). In the previous studies, while comparing the several factors before and after the pretreatment, there was a drastic increase in bulk density after pretreatment [6].

The moisture content of the raw biomedical waste before the pretreatment was 1.00 when PCB, and combination of pretreatment such as physical, chemical, and PCB pretreatment was performed, and there is a rapid increase in moisture content $44.2 \pm 4.05$ (Table 1 ). Kushwaha et al. achieved a moisture content of $40 \pm 2.05$ while assessing the moisture content of cotton waste [23].

The estimation of cellulose content was carried out to understand the amount of cellulose present before and after the pretreatment.

Table 1: Determination of physical parameters (bulk density, EC, pH, and moisture content) before and after the pretreatment

\begin{tabular}{|c|c|c|c|c|c|c|c|c|}
\hline \multirow{2}{*}{$\begin{array}{l}\text { Treatment } \\
\text { details }\end{array}$} & \multicolumn{2}{|c|}{ Bulk density (mg/m) } & \multicolumn{2}{|l|}{$E C\left(\mathrm{dSm}^{-1}\right)$} & \multicolumn{2}{|l|}{ pH } & \multicolumn{2}{|c|}{ Moisture content $(\%)$} \\
\hline & $\begin{array}{l}\text { Before } \\
\text { pretreatment }\end{array}$ & $\begin{array}{l}\text { After } \\
\text { pretreatment }\end{array}$ & $\begin{array}{l}\text { Before } \\
\text { pretreatment }\end{array}$ & $\begin{array}{l}\text { After } \\
\text { pretreatment }\end{array}$ & $\begin{array}{l}\text { Before } \\
\text { pretreatment }\end{array}$ & $\begin{array}{l}\text { After } \\
\text { pretreatment }\end{array}$ & $\begin{array}{l}\text { Before } \\
\text { pretreatment }\end{array}$ & $\begin{array}{l}\text { After } \\
\text { pretreatment }\end{array}$ \\
\hline \multicolumn{9}{|l|}{$\begin{array}{l}\text { Physical } \\
\text { pretreatment }\end{array}$} \\
\hline P1 & $0.59 \pm 0.22$ & $0.67 \pm 0.028$ & $0.33 \pm 0.17$ & $0.19 \pm 0.12$ & $6.9 \pm 0.087$ & $5.2 \pm 0.035$ & 1.00 & $29.2 \pm 0.60$ \\
\hline $\mathrm{P} 2$ & $0.59 \pm 0.22$ & $0.68 \pm 0.007$ & $0.33 \pm 0.17$ & $0.18 \pm 0.26$ & $6.9 \pm 0.087$ & $5.3 \pm 0.035$ & 1.00 & $29.7 \pm 0.25$ \\
\hline \multicolumn{9}{|l|}{$\begin{array}{l}\text { Chemical } \\
\text { pretreatment }\end{array}$} \\
\hline $\mathrm{C} 1$ & $0.59 \pm 0.26$ & $0.60 \pm 0.007$ & $0.33 \pm 0.17$ & $0.21 \pm 0.044$ & $6.9 \pm 0.087$ & $8.0 \pm 0.09$ & 1.00 & $14.40 \pm 0.66$ \\
\hline $\mathrm{C} 2$ & $0.59 \pm 0.26$ & $0.62 \pm 0.007$ & $0.33 \pm 0.17$ & $0.34 \pm 0.045$ & $6.9 \pm 0.087$ & $5.1 \pm 0.95$ & 1.00 & $19.11 \pm 1.66$ \\
\hline \multicolumn{9}{|c|}{$\begin{array}{l}\text { Biological } \\
\text { pretreatment }\end{array}$} \\
\hline B1 & $0.59 \pm 0.22$ & $0.71 \pm 0.014$ & $0.33 \pm 0.17$ & $0.38 \pm 0.24$ & $6.9 \pm 0.087$ & $7.8 \pm 0.268$ & 1.00 & $19.5 \pm 0.41$ \\
\hline B2 & $0.59 \pm 0.22$ & $0.73 \pm 0.042$ & $0.33 \pm 0.17$ & $0.41 \pm 0.03$ & $6.9 \pm 0.087$ & $7.6 \pm 0.127$ & 1.00 & $21.0 \pm 0.35$ \\
\hline B4 & $0.59 \pm 0.23$ & $0.76 \pm 0.063$ & $0.33 \pm 0.07$ & $0.47 \pm 0.007$ & $6.9 \pm 0.087$ & $7.4 \pm 0.014$ & 1.00 & $27.3 \pm 2.10$ \\
\hline B5 & $0.59 \pm 0.23$ & $0.76 \pm 0.063$ & $0.33 \pm 0.17$ & $0.51 \pm 0.03$ & $6.9 \pm 0.087$ & $7.2 \pm 0.155$ & 1.00 & $27.6 \pm 2.31$ \\
\hline B6 & $0.59 \pm 0.23$ & $0.79 \pm 0.070$ & $0.33 \pm 0.17$ & $0.54 \pm 0.05$ & $6.9 \pm 0.087$ & $7.1 \pm 0.226$ & 1.00 & $26.7 \pm 1.67$ \\
\hline \multicolumn{9}{|l|}{$\begin{array}{l}\text { Physical and } \\
\text { chemical } \\
\text { pretreatment }\end{array}$} \\
\hline PC1 & $0.59 \pm 0.22$ & $0.71 \pm 0.056$ & $0.33 \pm 0.17$ & $0.55 \pm 0.42$ & $6.9 \pm 0.087$ & $6.9 \pm 0.15$ & 1.00 & $7.6 \pm 0.82$ \\
\hline $\begin{array}{l}\text { PCB } \\
\text { pretreatment }\end{array}$ & & & & & & & & \\
\hline PCB1 & $0.59 \pm 0.23$ & $0.82 \pm 0.077$ & $0.33 \pm 0.17$ & $0.59 \pm 0.23$ & $6.9 \pm 0.087$ & $7.0 \pm 0.296$ & 1.00 & $44.2 \pm 4.05$ \\
\hline
\end{tabular}

$\mathrm{P} 1, \mathrm{P} 2, \mathrm{P} 3\left(121^{\circ} \mathrm{C}\right.$ for 15 minutes, $121^{\circ} \mathrm{C}$ for 60 minutes, and $121^{\circ} \mathrm{C}$ for 120 minutes, respectively) - Physical pretreatment; $\mathrm{C} 1, \mathrm{C} 2(0.25 \mathrm{M}$ NaOH pretreatment and $0.25 \mathrm{M}$ $\mathrm{HCl}$ pretreatment, respectively) - Chemical pretreatment, B1 to B6 - Biological pretreatment (Volume of Bacillus flexus (CFU) - $2 \times 10^{5}, 4 \times 10^{5}, 6 \times 105,8 \times 10^{5}, 10 \times 10^{5}$, and $12 \times 10^{5}$, respectively). PC1: Physical and chemical pretreatment, PCB1: Physical, chemical, and biological pretreatment, EC: Electrical conductivity, P: Physical, B: Biological, C: Chemical 
Table 2: Comparison of biochemical parameters (cellulose and carbohydrates) before and after the pretreatment

\begin{tabular}{|c|c|c|c|c|c|c|c|c|}
\hline \multirow[t]{3}{*}{ Treatment details } & \multicolumn{2}{|c|}{ Cellulose content (\%) } & \multicolumn{6}{|c|}{ Estimation of carbohydrate $(\mathrm{mg} / \mathrm{g})$} \\
\hline & \multirow{2}{*}{$\begin{array}{l}\text { Before } \\
\text { pretreatment }\end{array}$} & \multirow{2}{*}{$\begin{array}{l}\text { After } \\
\text { pretreatment }\end{array}$} & \multicolumn{3}{|c|}{ Before pretreatment } & \multicolumn{3}{|c|}{ After pretreatment } \\
\hline & & & $\begin{array}{l}\text { Total } \\
\text { sugar }\end{array}$ & $\begin{array}{l}\text { Reducing } \\
\text { sugar }\end{array}$ & $\begin{array}{l}\text { Non reducing } \\
\text { sugar }\end{array}$ & $\begin{array}{l}\text { Total } \\
\text { sugar }\end{array}$ & $\begin{array}{l}\text { Reducing } \\
\text { sugar }\end{array}$ & $\begin{array}{l}\text { Non reducing } \\
\text { sugar }\end{array}$ \\
\hline \multicolumn{9}{|c|}{ Physical pretreatment } \\
\hline P1 & $53 \pm 0.2$ & $51 \pm 1.4$ & $144 \pm 0.02$ & $137 \pm 0.01$ & $7 \pm 0.02$ & $115 \pm 0.36$ & $111 \pm 0.30$ & $4 \pm 1.64$ \\
\hline P2 & $53 \pm 0.2$ & $48 \pm 2.1$ & $144 \pm 0.02$ & $137 \pm 0.01$ & $7 \pm 0.01$ & $112 \pm 0.24$ & $106 \pm 0.49$ & $6 \pm 0.23$ \\
\hline P3 & $53 \pm 0.2$ & $47 \pm 2.8$ & $144 \pm 0.02$ & $137 \pm 0.01$ & $7 \pm 0.01$ & $108 \pm 0.58$ & $99 \pm 0.45$ & $9 \pm 1.88$ \\
\hline \multicolumn{9}{|c|}{ Chemical pretreatment } \\
\hline C1 & $53 \pm 0.2$ & $50 \pm 1.4$ & $144 \pm 0.01$ & $137 \pm 0.01$ & $7 \pm 0.03$ & $106 \pm 0.35$ & $94 \pm 0.60$ & $12 \pm 0.70$ \\
\hline $\mathrm{C} 2$ & $53 \pm 0.2$ & $46 \pm 2.8$ & $144 \pm 0.02$ & $137 \pm 0.02$ & $7 \pm 0.03$ & $105 \pm 0.35$ & $91 \pm 0.63$ & $14 \pm 0.71$ \\
\hline \multicolumn{9}{|c|}{ Biological pretreatment } \\
\hline B1 & $53 \pm 0.2$ & $43 \pm 2.1$ & $144 \pm 0.02$ & $137 \pm 0.03$ & $7 \pm 0.01$ & $102 \pm 4.00$ & $88 \pm 0.75$ & $14 \pm 3.18$ \\
\hline B2 & $53 \pm 0.2$ & $42 \pm 2.4$ & $144 \pm 0.02$ & $137 \pm 0.03$ & $7 \pm 0.01$ & $100 \pm 2.59$ & $84 \pm 0.88$ & $16 \pm 1.76$ \\
\hline B3 & $53 \pm 0.2$ & $41 \pm 0.7$ & $144 \pm 0.02$ & $137 \pm 0.02$ & $7 \pm 0.02$ & $98 \pm 1.18$ & $80 \pm 0.81$ & $18 \pm 0.35$ \\
\hline B4 & $53 \pm 0.2$ & $39 \pm 0.7$ & $144 \pm 0.01$ & $137 \pm 0.02$ & $7 \pm 0.02$ & $95 \pm 0.94$ & $79 \pm 0.91$ & $16 \pm 1.76$ \\
\hline B5 & $53 \pm 0.2$ & $37 \pm 2.1$ & $144 \pm 0.02$ & $137 \pm 0.01$ & $7 \pm 0.04$ & $92 \pm 3.06$ & $72 \pm 1.66$ & $20 \pm 1.06$ \\
\hline B6 & $53 \pm 0.2$ & $32 \pm 3.5$ & $144 \pm 0.02$ & $137 \pm 0.01$ & $7 \pm 0.04$ & $91 \pm 3.76$ & $64 \pm 3.22$ & $27 \pm 3.01$ \\
\hline \multicolumn{9}{|c|}{$\begin{array}{l}\text { Physical and chemical } \\
\text { pretreatment }\end{array}$} \\
\hline PC1 & $53 \pm 0.2$ & $40 \pm 4.5$ & $144 \pm 0.01$ & $137 \pm 0.02$ & $7 \pm 0.02$ & $97 \pm 0.47$ & $86 \pm 0.73$ & $11 \pm 1.51$ \\
\hline \multicolumn{9}{|l|}{ PCB pretreatment } \\
\hline PCB1 & $53 \pm 0.2$ & $32 \pm 3.5$ & $144 \pm 0.01$ & $137 \pm 0.01$ & $7 \pm 0.03$ & $83 \pm 6.42$ & $59 \pm 4.31$ & $24 \pm 3.88$ \\
\hline
\end{tabular}

$\mathrm{P} 1, \mathrm{P} 2, \mathrm{P} 3\left(121^{\circ} \mathrm{C}\right.$ for 15 minutes, $121^{\circ} \mathrm{C}$ for 60 minutes, $121^{\circ} \mathrm{C}$ for 120 minutes) - Physical pretreatment, $\mathrm{C} 1, \mathrm{C} 2(0.25 \mathrm{M} \mathrm{NaOH}$ pretreatment and $0.25 \mathrm{M} \mathrm{HCl}$ pretreatment, respectively) - Chemical pretreatment, B1 to B6 - Biological pretreatment (Volume of Bacillus flexus (CFU) - $2 \times 10^{5}, 4 \times 10^{5}, 6 \times 10^{5}, 8 \times 10^{5}, 10 \times 10^{5}$, and $12 \times 10^{5}$, respectively), PC1: Physical and chemical pretreatment, PCB1: Physical, chemical, and biological pretreatment, P: Physical, B: Biological, C: Chemical

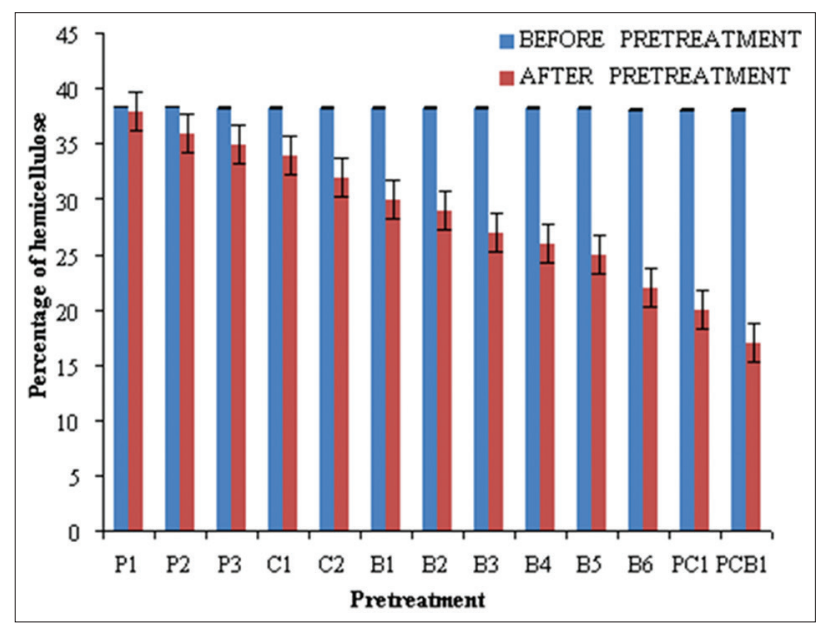

Fig. 1: Analysis of hemicellulose content in before and after pretreated biomedical wastes

When comparing the before and after pretreatments, the percentage of cellulose level was reduced drastically (Table 2). After the physical pretreatment $(\mathrm{P})$, cellulose content was reduced to $4 \%$, and in chemical pretreatment $(\mathrm{C})$, the cellulose content was reduced to $8 \%$. In biological pretreatment (B), the cellulose content was reduced to $28-30 \%$. The percentage of cellulose level reduction was found to be $35-40 \%$ in PCB method. In the subsequent study, the estimation of cellulose content in wood, paper, and pulp was carried out, and cellulose content after the biological pretreatment was 19\% [24].

After the physical pretreatment (P), hemicelluloses content was reduced to 2\% (Fig. 1). In chemical pretreatment (C), the cellulose content was reduced to $4 \%$. The cellulose content was reduced to $7-9 \%$ in biological pretreatment. The percentage of hemicellulose level reduction was found to be $23-26 \%$ in PCB method. Blasi et al. achieved $18 \%$ reduction of hemicellulose while assessing the cellulose content in paper and pulp [19].
The Amount of carbohydrate content (total sugar, reducing sugar, and non-reducing sugar) before the pretreatment was found to be $144 \pm 0.02,137 \pm 0.03$, and $7 \pm 0.01 \mathrm{mg} / \mathrm{g}$, respectively, and after the pretreatment process, there is a reduction in the total sugar content, reducing sugar, and non-reducing sugar $(83 \pm 6.42,59 \pm 4.31$, and $24 \pm 3.88 \mathrm{mg} / \mathrm{g}$, respectively) (Table 2). Lee et al. achieved the result that there was a rapid decrease in the percentage of sugar content during the pretreatment of cellulose [9].

\section{CONCLUSION}

The present investigation proved that the pretreatment methods are effective in reducing the cellulosic content and changing the physiochemical parameters of the biomedical waste. Among the pretreatment methods, the combination of PCB methods are the best due to the presence of B. flexus. The pretreated biomedical waste can be used as a substrate for the production of vermicompost and biogas because of the suitable physiochemical properties.

\section{ACKNOWLEDGMENT}

The authors would like to thank the Management of Karpagam University, Karpagam Academy of Higher Education, Coimbatore, Tamil Nadu, India, for providing necessary facilities to carry out this work.

\section{REFERENCES}

1. Benedict RG, Carlson D. Aerobic heterotrophic bacteria in activated sludge. Water Res 1971;5:1023-30.

2. Li S, Xu S, Liu C. Fast pyrolysis of biomass in free-fall reactor for hydrogen-rich gas. Fuel Process Technol 2004;85(8-10):1201-11.

3. Harhay MO, Halpern SD, Harhey JS, Olliaro PL. Health care waste management a neglected and growing public problem worldwide. Trop Med Int Health 2009;58:17-23.

4. Bitton G. Wastewater Microbiology. $3^{\text {rd }}$ ed. Hoboken, New Jersey: A John Wiley \& Sons Inc.; 2005. p. 345-69.

5. Anitha $\mathrm{J}$, Indira $\mathrm{AJ}$. Isolation and identification of bacteria from biomedical waste (BMW). Int J Pharm Pharm Sci 2012;4(5):286-388.

6. Hoffman RM, Wood TM. Isolation and partial characterization of a mutant of Penicillium funiculosum for the saccharification of straw. Biotechnol Bioeng 1985;27(1):81-5. 
7. Almuneef M, Memish ZA. Effective medical waste management: It can be done. Am J Infect Control 2003;31(3):188-92.

8. Ball AS, Betts WB, McCarthy AJ. Degradation of ligninrelated compounds by actinomycetes. Appl Environ Microbiol 1989;55(6):1642-4.

9. Lee SM, Koo YM. Pilot-scale production of cellulose using Trichoderma reesei Rut C-30 in fed-batch mode. J Microbiol Biotechnol 2001;11(2):229-33

10. Lynd LR, Wyman CE, Gerngross TU. Biocommodity engineering. Biotechnol Prog 1999;115(3):223-32.

11. Ohkuma M. Symbioses of flagellates and prokaryotes in the gut of lower termites. Trends Microbiol 2008;16:345-52.

12. Tahoun MK, Ibrahim AA. Conversion of natural cellulosic substrates into fermentable sugar by recombinant Fungi strain. J Environ Sci 1999;208:65-8.

13. Singh J, Batra N, Sobt RC. A highly thermostable alkaline CMCase produced by a newly isolated Bacillus sp.VG1. World J Microbiol Biotechnol 1998;17(8):761-5.

14. Mandels M, Anderotti R, Rochec C. Measurement of saccharifying cellulase. Biotechnol Bioeng 1976;95:391-414.

15. Jackson ML. Soil Chemical Analysis. New Delhi: Prentice Hall of India Pvt. Ltd.; 1973. p. 10-50.
16. Sun XF, Xu F, Sun RC, Fowler P, Baird MS. Characteristics of degraded cellulose obtained from steam-exploded wheat straw. Carbohydr Res 2005;340:97-106.

17. Balat M, Balat H, Oz C. Progress in bioethanol processing. Prog Energy Combust Sci 2008;34(5):551-73.

18. Updegraff DM. Semimicro determination of cellulose in biological materials. Anal Biochem 1969;32(3):420-4

19. Blasi CD, Signorelli G, Di Russo, Rea G. Product distribution from pyrolysis of wood and agricultural residues. Ind Eng Chem Res 1990;38(6):2216-24.

20. Miller GL. Use of dinitrosalicylic acid reagent for determination of reducing sugar. Anal Chem 1959;31(3):426-8.

21. Hansen J, Moller IB. Percolation of starch and soluble carbohydrates from plant tissues for quantiative determination with anthrone. Anal Biochem 1975;68(1):87-94.

22. Duff S, Murray JB. Bioconversion of forest products industry waste cellulosics to fuel ethanol: A review. Bioresour Technol 1996;55:1-33.

23. Kushwaha JP, Srivastava VC, Mall ID. An overview of various technologies for the treatment of dairy wastewaters. Crit Rev Food Sci Nutr 2011:51:442-52.

24. Yin L, Lin H, Xiao Z. Purification and characterization of cellulose from Bacillus sustilis YJI. J Marine Sci Technol 2010;18:466-71. 